\title{
De yderste ting
}

I

I foråret 1996 blev jeg spurgt om jeg kunne tænke mig at tage nordpå for at skrive en artikel eller et essay om en af skulpturerne i det projekt som bliver kaldt Skulpturlandskap Nordland. I dette Artscape Nordland har billedhuggere som Per Kirkeby, Markus Raetz, Kain Tapper og mange andre fået lov til at udføre en skulptur i hver sin kommune fra Trøndelag til langt nord for polarcirklen.

Jeg vidste at den italienske billedhugger Luciano Fabro var med i projektet. I og med at jeg sætter stor pris både på ham og på 'Arte povera' i det hele taget, sagde jeg entusiastisk ja til at tage ud til Røst for at give en skildring af Fabros skulptur på denne $\varnothing$ yderst i Lofoten.

Billetterne kom med posten, jeg pakkede kufferten, tog ud til Fornebu og tog en DC-9 til Bodø i månedsskiftet mellem maj og juni. I Bodø skiftede jeg til en Twin Otter, eller måske var det en Dash 7, i hvert fald flaksede jeg i et lille fly over Vestfjorden til Leknes i Lofoten og videre ud til Røst.

Der var sandt at sige ikke mange fremmede passagerer som stod af flyet. Så jeg fik let fat på den lokale taxa og bad om at blive kørt til Fiskarheimen Havly, som ligger helt på den modsatte side af Røstlandet. Fra taxaens bagsæde så jeg ud over et folketomt og uigennemtrængeligt norsk landskab. Ikke et menneske var at se, kun tørrestilladser med tørfisk, som svingede i vinden, og store hvalharpuner, som var sat op til pynt, eller som et forsvar mod Greenpeace, ved indgangspartierne til de spredte enfamiliehuse.

På Fiskarheimen var jeg den eneste gæst, med en kafkaagtig undtagelse. To italienske fiskeopkøbere sad i spisesalen og vansmægtede og ventede på fiskepladsens ejer, Jentoft, som aldrig kom tilbage fra en forretningsrejse. De havde vist ventet både vinter og vår, for de var så deprimerede at de lå hen over bordet i spisesalen med hovedet i hænderne ved siden af den urørte tallerken med løvbiff og fyrstekake, som de sikkert havde bestilt til morgenmad tre dage tidligere. 
Da de opdagede mig, løftede de lige akkurat på hovedet og spurgte med et meget lille glimt af håb i øjnene:

Amico Jentoft?

Amico no, måtte jeg svare, som sandt var.

Dermed faldt de hen over bordet og endnu dybere ned i depressionen igen.

Jeg for min del måtte klare mig med et kompromisløst dårligt værelse i den nye fløj på Fiskarheimen, og jeg fik desuden fundet ud af at Luciano Fabros statue var flyttet.

Den stod ikke længere ude på det flade Røstland, sådan som jeg havde set på billeder. Nu var den fjernet derfra og i stedet sat op igen ude på Vedøya, som ligger længere ude i Røstarkipelet, i retning af fjeldene på Utrøst og Skomvær fyr.

Men jeg havde før været ude en vinterdag, og jeg gav mig ikke så let. Jeg satte mig til at fodre telefonboksen uden for receptionen med mønter, og jeg fik til sidst fat på en færgemand, som var villig til at sejle mig til Vedøya.

Den næste morgen kom han ganske som aftalt. Jeg gik om bord, og vi drog på havet i sol og prima vejr, med tunge dønninger ind fra det åbne hav mod vest.

Jeg stod foran i styrehuset og talte mandigt med skipperen, og alt så fint og godt ud. Men så, et par hundrede fod fra land, satte han pludseligt motoren i tomgang, og vi blev liggende og gyngede i bølgerne. Vi var ved vejs ende. Længere ind mod Vedøya turde han ikke gå med båden. I stedet firede vi en robåd i vandet, og jeg satte mig ved årerne for at ro det sidste stykke ind til land.

Fint nok, moderne kunst skal jo være vanskelig tilgængelig, tænkte jeg, og roede indad som jeg bedst kunne og fortøjede i lavvande.

Foran mig rejste en dybgrøn græsbevokset bakke sig, og bag den rejste sig et højt, sort fjeld. Intenst grønt mod fuldstændigt sort. På kanten mellem den græsbevoksede bakke og fjeldet kunne jeg nu se omridset af Luciano Fabros "Il Nido" omtrent som et får i græsset, bare lidt større, bare lidt hvidere.

Det tog mig et par minutter at gå op ad den stejle græsbevoksede bakke. Så nærmede jeg mig skulpturen. Den står direkte på jorden, uden fundament, nøjagtig der hvor bakkekammen igen begynder at skråne ind mod fjeldsiden.

Der er kun mig og kunstværket. Ellers er alt mennesketomt og øde.

Da sker der pludseligt noget.

Der sker noget helt mærkværdigt.

Det sorte fjeld slår sine vinger ud.

Det sorte fjeld slår tusind vinger ud.

Det sorte fjeld letter og begynder at svæve over mig.

Det sorte fjeld bliver stærkt hvidt.

Og det hvide svævende fjeld begynder at synge.

Fjeldet svæver over mig og synger med tusinde struber.

Og jeg står under et svævende, syngende stærkthvidt fjeld og ser ned på Luciano Fabros skulptur "Il Nido", der betyder "Reden", og som består af to udsnit af klassiske søjler, i hvid marmor, stillet på skrå mod hinanden, med to-tre glatte marmoræg i kløften som opstår mellem de to søjleudsnit.

Under det svævende fjeld som synger med tusinde struber og ved siden af kunstværket står jeg og fornemmer at det begynder at regne hvidt ned over mig. Jeg ser op, og ser at det er det hvide, syngende fjeld som skider på mig. 
På mange måde kan man se Luciano Fabros "Il Nido" på Vdøya udenfor Røst i Nordland som et præcist udtryk for kunstens plads i det senmoderne samfund.

Geografisk er skulpturen placeret i den ekstreme udkant.

Den er ekstremistisk, ved de yderste grænser.

Den er fuldstændig marginaliseret.

Den er upopulær. Den er meget vanskeligt tilgængelig, i den forstand at den kræver store ressourcer, i form af tid og penge, og økonomisk såvel som kulturel kapital for at kunne opleve den. Min egen kunstoplevelse på Vedøya er kraftigt subsidieret af det offentlige, gennem rejsepenge, diæter og honorar.

Den er af høj håndværksmæssig og ideologisk kvalitet.

Den er stærkt omstridt. Med installationerne på de yderste nøgne holme og skær er Skulpturlandskap Nordland blevet et omdrejningspunkt for en hidsig politisk og ideologisk debat om kunstens væsen og kunstens placering. Skulpturlandskap Nordland repræsenterer yderpunktet på den ene side i debatten. I mere smult farvand, længere inde i området, sejler de nye hurtigruteskibe op og ned langs kysten som trawlerfabrikker for en mere agterudsejlet kunstopfattelse. Det er den anden modpol.

I modsætning til hurtigrutekunsten er Luciano Fabros "Il Nido" international. Den er hverken landskabsrelevant eller national.

Samtidig er den både stedsbundet og partikularistisk.

Den er en del af et offentligt styret kunstprogram. Efter alt at dømme er den alligevel sat op tværs mod folkeviljen og mod en bred opinion.

Den er elitær eller elitistisk.

Den vil ikke være kunst. Tværtimod vil den være antikunst, negationen af kunst. Her finder man den fuldkomne overensstemmelse mellem kunstnerens intention og det synspunkt som færgemanden på min båd stod for.

Den udtrykker kunsten som senmoderne ideologi. Eller mere præcist: Kunsten som ideologi for det senmoderne.

Den giver ikke bare et kunstnerisk perspektiv på landskabet. I landskabet organiserer den også et metaperspektiv på kunsten.

III

Her er det på sin plads at minde om at jeg står ved siden af et avanceret moderne kunstværk, som ikke vil være kunst, og som er placeret som en kunstnerisk udsmykning på en mennesketom holm midt ude i Nordatlanten ved hjælp af amtskommunale midler og en stor offentlig indsats.

Dette sted for kunst er det ofte umuligt og altid vanskeligt at nå frem til når vi andagtsfulde og selvudslettende trasker rundt i samtidsmuseerne for transcendens, på vej mod caféen, som har det samme elegante interiør og den samme velsmagende og lidt slappe mad overalt på kloden.

Måske er det lettere at nærme sig dette vanskeligt tilgængelige sted med robåd, i dønningerne, og derefter til fods, gennem det høje græs, fårelorten og fugleskrigene, alene, og langt fra mennesker, ude på Vedøya i Nordatlanten? Under det syngende, skrigende fjeld som skider på en? 
I litterær sammenhæng er vi da på skriftstederne som tilhører forfattere som for eksempel Ole Robert Sunde, Svein Jarvoll, Steinar Løding, for nu at holde os til en norsk sammenhæng.

Der ude, i den yderste periferi, ved siden af marmorreden, der hvor Luciano Fabro virkeligt har lagt æg, når vi frem til en helt særlig formulering af forholdet mellem det specifikke og det almene, mellem det lokale og det internationale, mellem tiden og stedet, mellem kunsten og benægtelsen af kunsten, mellem centrum og udkant, mellem industrisamfundets Metropolis og den informationskapitalistiske Logopol. Måske nærmer vi os også "the centrality of margins" som Beatriz Sarlo taler om i sit arbejde om Jorge Luís Borges.

Men når jeg har stået sådan og tænkt et stykke tid, har jeg fået nok af fuglelort, mågeskrig og udkant. Jeg går ned igen til plastjollen og ror ud til båden, som bruger spillet på dækket til at hejse mig om bord igen.

Vi sætter farten op og går i medvind indover mod det flade Røstland. Da jeg vender mig om og ser tilbage svæver og synger fjeldet ikke længere. Det er landet. Det er helt stille, og ude på Vedøya står fjeldet sort op fra den grønne græsbegroede bakke.

Fra indsejlingen til Glea og Fiskarheimen ser Luciano Fabros "Il Nido" ikke længere ud som et får, bare lidt større, bare lidt hvidere. Den er en fugl som er landet på hvide vinger af marmor og ligger og ruger fantasifostre ud af sine glatte æg.

Oversat af Max Ipsen. 